\begin{tabular}{|c|c|c|c|c|c|} 
Mansoura University \\
Faculty of Engineering \\
Mansoura Engineering Journal
\end{tabular}

\title{
Improvement of Drinking Water Properties Using a Novel Biosorbent Material
}

\author{
Mohammed Hussein, Mohamed Gar-Alalm and Hisham Kh. El-Etriby
}

KEYWORDS:
Coagulation,
Adsorption,
Modified flaxseed husk
(MFH),
Flaxseed husk ash
(FHA),
Turbidity,
Natural organic matter,
Iron
kinetics
Isotherm

\begin{abstract}
In the present study, a new material has been discovered in the world of natural coagulants and adsorbents to improve drinking water properties. Flaxseed husk was used as a natural coagulant and adsorbent to remove turbidity, natural organic matter and iron from underground water for several wells in Al-Jouf region in the north of the Kingdom of Saudi Arabia. To remove turbidity and natural organic matter, modified flaxseed husk (MFH) was prepared by addition of aluminum sulfate (AS) to flaxseed husk (FH) after removing mucilage and oil. The characterization of FH shows high specific surface area $(125.18 \mathrm{~m} 2 / \mathrm{g})$ with average pore diameter of $26.28 \mu \mathrm{m}$. Moreover, FTIR spectra analysis indicated existence of large number of amino groups and another functional group indicated that FH efficiency about removal of turbidity and natural organic matter. The optimum ratio MFH:AS for removal was $(80 \%: 40 \%)$. Batch experiments were performed as function of process parameters such as slow mixing time, FH dosage and Initial NOM. The removal of turbidity and natural organic matter (NOM) by modified flaxseed husk (MFH) were investigated using a FH dosage of $40 \mathrm{mg} . \mathrm{l}-1$ and $10 \mathrm{mg} . \mathrm{l}-1 \mathrm{AS}$ which attained a removal efficiency of $98.0 \%$ for turbidity and 99.3\% for NOM at the highest NOM concentration. Also, reduce the iron concentration in drinking water by flaxseed husk ash (FHA) which prepared by burning flaxseed husk at certain temperature was investigated. Batch experiments were performed as function of process parameters such as FHA type, contact time (CT), FHA dosage and initial Fe concentration. The FHA showed a high removal of Fe3+ from aqueous solution. The maximum Fe removal was $90 \%$ at FHA200, FHA dose 0.75 $\mathrm{g} / \mathrm{l}$ and contact time $45 \mathrm{~min}$, The $\mathrm{pH}$ value from 7 to 7.8 and the temperature value from 20 to $24 \mathrm{0C}$. The adsorption equilibrium has been studied by the pseudo first order kinetics model, the pseudo second order kinetics model, Langmuir and Freundlich isotherm, all these models demonstrated the adsorption efficiency of the adsorbent surface behaved in a favorable manner for Fe adsorption.
\end{abstract}

Received: (10 October, 2019) - revised: (19 January, 2020) - accepted: (31 August, 2020)

Hisham Kh. El-Etriby, Assoc. Prof., Head of Public Works Dept., Faculty of Engineering, Mansoura University. E-mail: eletribyhk@yahoo.com

Mohamed Gar-Alalm, Dr., Lecturer at Public Works Department, Faculty of Engineering, Mansoura University.E-mail: m_gar_alalm@yahoo.com

Mohammed Hussein, M.Sc. Student, Public Works Department, Faculty of Engineering, Mansoura University. E-mail: hssn_moh@yahoo.com

\section{INTRODUCTION}

7 HE existence of turbidity and natural organic matter (NOM) in drinking water has received considerable attention in recent decades because it can lead to odor, color and taste problems in addition to formation of disinfection by-products (DBPs) [1]. NOM is widely detected in most water sources such as lakes and rivers [2]. It has been reported that most of NOM in surface and ground water is in the form of humic and fulvic acids [3]. Humic and fulvic acids react with chlorine-based materials during the disinfection process and hence DBPs are formed. DBPs are carcinogenic 
and cause many health and environmental problems to human and aquatic life [4,5].

Chemical coagulation using aluminum sulphate followed by sedimentation and filtration is the most prevalent sequence in water treatment plants. These basic processes are efficient for the removal of colloidal or suspended particles, but the removal of NOM is limited [6]. Some researches have addressed improving the coagulation process to remove turbidity and NOM by adjusting the $\mathrm{pH}$ of the water and increasing the amount of coagulant, but the high amount of chemical addition was a concern [7]. Lieknes et al. (2004) investigated the micro-filtration by metal membranes as a post process after coagulation for NOM removal [8]. However, the cost of micro-filtration was not considered.

Many researchers have used the adsorption by activated carbon and advanced oxidation processes for removing or degradation of different organics from water [9-12]. While, other researchers have developed low cost adsorbent materials that prepared from agricultural residues such as wheat straw [13], rice husk [14], peanut hull, coconut husk [15], black gram husk [16], Sawdust [17], sugarcane bagasse [14], banana pith [18], and pine grape stalk [16].

Globally, surface water is the main source of water in the world by up to 73 percent, followed by groundwater by up to 18 percent. While indirect sources represent the remaining fraction of less than 9 percent [19]. The majority of freshwater is already underground, represented by soil moisture and aquifers. Humans can use both ground and surface water. Groundwater accounts for 19.3 percent of the world's human consumption [20]. While in some countries such as Saudi Arabia, groundwater represents $40 \%$ of drinking water after seawater desalination, which represents the highest percentage $[21,22]$.

Underground water contains mineral substances. The presence of these minerals in groundwater varies from place to another_depending on the nature of the soil and the depth of the aquifers extracted from it. Some of these minerals are iron. Some of these subterranean sources contain iron ions with values in excess of what is allowed in drinking water or human use [23]. There is a need for the emergence of many ways to remove the minerals in this water, including: Sedimentation or precipitation processes, ion exchange, membrane techniques, biological methods, electrochemical processes as well as adsorption [24]. The threshold values for iron are set by the Saudi Arabian government regulation according to Gulf Standard Specification for unbottled drinking water No. $149 / 2000$ is 0.3 mg..$^{-1}$ which specifying the requirements on water for human consumption and the quality of water for human consumption and match with United States Environmental Protection Agency (EPA) [25-27], while the requirements of the Standardization Organization of the Gulf Cooperation Council states that the health value of iron in bottled water is zero $[27,28]$. Iron occurs in the binary form or occurs as single ions $\left(\mathrm{Fe}^{2+}\right)$ when it is in a dissolved form, but mainly as $\mathrm{Fe}(\mathrm{OH})_{3}$ in undissolved forms. It can also be occurred bound to humic substances in a colloid form. The form in which iron is occurred and its composition in nature depends on water temperature, $\mathrm{pH}$ value, hydrolysis, the oxygen concentration in the aqueous solution (probability of oxidation or not), the solubility of iron compounds in water and iron binding to organic compounds or non-binding [29].

According to the EPA, the presence of iron ions at high levels in water carries bacteria into stomach, causing severe damage during digesting including fatigue, weight loss, stomach problems, nausea, vomiting and joint pain. Advanced symptoms include hemochromatosis which can lead to liver, heart and pancreatic damage, as well as diabetes [30]. In water supply system, iron (II) ion is oxidized to higher forms and the result of this oxidation leads to the formation of hydroxide suspensions causing water discoloration and undesirable turbidity. In well water, when Fe(II) occurs at concentrations up to be more specific milligrams per liter in anaerobic groundwater, color change or turbidity does not occur in the water when pumped directly from a well, but this develops overtime to produce color and turbidity in distribution pipe system at iron level above $0.05-0.1 \mathrm{mg} . \mathrm{l}^{-1}$ [31].

One of the damages caused by the association of bacteria with iron in the distribution pipes over time causes the growth of bacteria and a large change in the water smell. This causes the formation of a thin layer coating the inside pipes. Iron is at the point of consumption, in washing machines and boilers oxidized to the triple state when conditions are favorable in the presence of oxygen [29-31]. All of the previous problems cause a reduction in the cross-section of water flow in pipes, corrosion and deterioration of water quality. This leads to failure of operation of water supply systems [29].

In this paper, first: Chemically modified flaxseed husk (MFH) was used for drinking water treatment. MFH was prepared by addition of aluminum sulfate to flaxseed husk (FH) after removing the mucilage and oil. The removal of turbidity and NOM by coagulation and adsorption using MFH was deeply investigated. Second: Reduce the concentration of iron in drinking water by flaxseed husk ash (FHA) prepared by burning flaxseed husk at certain temperature to achieve the specifications in accordance with the specifications of the Gulf Cooperation Council Water No. 149 / 2000. The study was conducted on a group of wells for drinking water in several fields in Al-Jowf region in the north of Saudi Arabia. The byproduct of the flaxseed husk ash after removing oil was used as an absorbent material for the iron element. However, it was found that the measurements of manganese ratios in the studied wells are $0.1 \mathrm{mg} . \mathrm{l}^{-1}$, i.e. within the permissible range according to the World Health Organization, which specified that manganese should not exceed $5 \mathrm{mg}$ per liter. 


\section{Materials and methods}

\section{A. Materials and raw water}

Flaxseed was purchased from a local market and stored at room temperature, the by-product which is the result of pressing flaxseed from an Oil refinery in Jeddah city, Saudi Arabia. $\left(\mathrm{Al}_{2}\left(\mathrm{SO}_{4}\right)_{3} \cdot 16 \mathrm{H}_{2} \mathrm{O}\right.$, n-hexane, Whatman filter paper grad 1 and $\mathrm{NaHCO}_{3}$ were purchased from SOMAT-CO, ElRiyadh City. The raw water was collected from different wells in Skaka, Al Jowf, Saudi Arabia. The characteristics of raw water are illustrated in Table 1. All the experiments were conducted without prior modifications of samples.

TABLE. 1

PHYSICOCHEMICAL CHARACTERISTICS OF RAW WATER.

\begin{tabular}{c||c||c||c} 
Temperature ${ }^{\circ} \mathrm{C}$ & $\mathrm{pH}$ & $\begin{array}{c}\text { Turbidity } \\
(\mathrm{NTU})\end{array}$ & $\mathrm{UV}_{254}\left(\mathrm{~cm}^{1}\right)$ \\
\hline $20-24$ & $7.0-7.8$ & $4.0-9.5$ & $0.05-0.44$ \\
$\mathrm{Fe}\left(\mathrm{mg} . \mathrm{l}^{-1}\right)$ & $\begin{array}{l}\text { T.D.S }(\mathrm{mg} . \\
\left.\mathrm{l}^{-1}\right)\end{array}$ & $\mathrm{Mn} \mathrm{mg.} \mathrm{l}^{-1}$ & $\begin{array}{c}\text { Conductivity } \\
\left(\mu \mathrm{s} . \mathrm{cm}^{-1}\right)\end{array}$ \\
\hline $0.13-1.72$ & $975-989$ & 0.1 & $1400-1408$
\end{tabular}

\section{B. Apparatuses and instruments}

Stirrer 1: AGIMATIC AD-C magnetic Stirrer, Stirrer 2: ARE Heating magnetic Stirrer VELP scientific, Refrigerator Deodorizer SAMSUNG, Blender GEEPAS, Whatman filter paper grad 1 and Packers of different sizes from $200 \mathrm{ml}$ to 1 liter. Digit heat JP Selecta serial 0494926 was used to burn samples. HACH SENSION3 $\mathrm{pH}$ meter was used to measure $\mathrm{pH}$. Ultra-meter $\Pi$ 6P MYRON L company was used to measure Conductivity $\left(\mu \mathrm{s} . \mathrm{cm}^{-1}\right)$, T.D.S $\left(\mathrm{mg} . \mathrm{l}^{-1}\right)$ and Temperature (0C). Analytical Balance GR-120 MODEL A\&D company was used to determine weight, $2100 \mathrm{P}$ turbidimeter HACH company was used to measure turbidity (NTU). The bandgap of synthesized MFH was determined by using Spectrophotometer DR 5000 HACH company. A BrunauerEmmett-Teller (BET) analysis was performed to determine the surface area and pore size for flaxseed husk (FH), which is done using the automatic Belsorp-max device using liquid adsorption N2 at a temperature of $77 \mathrm{~K}\left(-196.15^{\circ} \mathrm{C}\right)$. Fourier transform infrared spectrometry (FTIR) was used to determine the functional group. On A PerkinElmer "Spectrum BX" spectrometer in the range of $4000-400 \mathrm{~cm}^{-1}$ was used $\mathrm{KBr}$ pellets for sample preparation.

\section{Extraction and Experimental procedure}

In this section, the process of the preparation modified flaxseed husk (MFH) from raw flaxseed was illustrated, including the removing of mucilage and oil and improving the flaxseed husk characteristic by blending it with aluminum sulphate (AS). The preparation of the flaxseed husk ash (FHA) by burning flaxseed husk at certain temperatures $\left(75,100,150,200{ }^{\circ} \mathrm{C}\right)$. and experimental procedures which were used to remove turbidity, natural organic matter and iron were illustrated.

\section{A. Preparation of modified flaxseed husk (MFH)}

\section{1) Remove mucilage and oil from seeds}

To remove the flaxseed mucilage, first, 50 milligrams of flaxseed were weighed and washed with distilled water to remove dust. Then, half a mole $(0.5 \mathrm{M})$ of sodium bicarbonate $\mathrm{Na} \mathrm{HCO}_{3}\left(1: 8 \mathrm{w} / \mathrm{v}, 40^{\circ} \mathrm{C}\right)$ was put in a half-liter baker. Then, the washed seeds were added to the sodium bicarbonate. After that, the baker was placed on the magnetic stirrer, set at $40{ }^{\circ} \mathrm{C}$ for an hour, then filtered with a cloth filter to separate the liquid (mucilage) for disposal. The solid which is left (flaxseed without mucilage) washed several times with distilled water, dried and kept at room temperature $\left(24^{\circ} \mathrm{C}\right)$ for 24 hours. This new product (flaxseed without mucilage) is called (F-OUT m) [32].

After removing the mucilage, the oil was removed from the flaxseed (F-OUT M) by the following steps: The seeds (FOUT M) were crushed by a laboratory mill and the $n$-hexane was added in a 1-liter baker (1:5, w/v) and placed on the magnetic stirrer for 6 hours. Regeneration of n-hexane every 2 hours by paper filters. After final filtration the resulting material is left in the dark to dry at room temperature exposed to air and then stored at $4{ }^{\circ} \mathrm{C}$ and called (FH-OUT M, O) [32].

To determine the functional group, FITR Fourier transform infrared spectrometry test performed on A PerkinElmer "Spectrum BX" spectrometer in the range of 4000-400 cm-1 using $\mathrm{KBr}$ pellets for sample preparation was used. A Brunauer-Emmett-Teller (BET) analysis was performed to determine the surface area and pore size for flaxseed husk $(\mathrm{FH})$, which was done using the automatic Belsorp-max device using liquid adsorption N2 at a temperature of $77 \mathrm{~K}$ [32].

\section{2) Modification of $\left(\mathrm{FH}-\mathrm{OUT} \mathrm{M}_{\mathrm{M}} \mathrm{O}\right)$}

(FH-OUT M, o) was then used with aluminum sulphate (AS), as a mixed coagulant with a certain dosage. $25 \mathrm{mg} . \mathrm{l}^{-1}$ for (AS) and $50 \mathrm{mg} . \mathrm{l}^{-1}$ for (FH-OUT $\mathrm{M}, \mathrm{o}$ ) were used as a coagulants dosages specified on (Table 2) [33-35]. Operational conditions of the coagulation / flocculation and sedimentation process was used in seed correlation (FH-OUT $\mathrm{M}, \mathrm{O}$ ) and alum coagulants were presented in (Table 3). After the coagulation / flocculation and sedimentation process was completed, samples which were taken $3 \mathrm{~cm}$ under the water surface was filtered by Whatman paper filter grad 1 (pore size of $0.6 \mu \mathrm{m}$ ). Finally, the residual turbidity and NOM were quantified by $2100 \mathrm{P}$ Turbidimeter Hach Co, and spectrophotometer DR 5000 Hach Co respectively [36,37]. 
TABLE. 2

COAGULANTS DOSAGE COMBINATION.

\begin{tabular}{|c|c|c|c|}
\hline \multirow[b]{2}{*}{ POINT } & \multirow{2}{*}{$\begin{array}{c}\% \text { Coagulant } \\
\left(\mathrm{Al}_{2}(\mathrm{SO4})_{3.16 H 2 O} /\right. \\
\left.\text { FH-OUT }_{M, 0}\right)\end{array}$} & \multicolumn{2}{|c|}{ Coagulant dosage (mg. $\left.\mathrm{l}^{-1}\right)$} \\
\hline & & $\mathrm{Al}_{2}(\mathrm{SO} 4)_{3.16 H 2 O}$ & FH-OUT $_{M, o}$ \\
\hline 1 & $0 \%, 100 \%$ & 0 & 50 \\
\hline 2 & $20 \%, 80 \%$ & 5 & 40 \\
\hline 3 & $40 \%, 60 \%$ & 10 & 30 \\
\hline 4 & $60 \%, 40 \%$ & 15 & 20 \\
\hline 5 & $80 \%, 20 \%$ & 20 & 10 \\
\hline 6 & $100 \%, 0 \%$ & 25 & 0 \\
\hline
\end{tabular}

\section{B. Experimental procedure and the analytical measurements of $(M F H)$}

The hybrid process including coagulation and adsorption was carried out as follows: first: coagulation followed by adsorption, second: adsorption followed by coagulation.

Coagulation and subsequent adsorption tests were performed after collection of samples after sedimentation, and then different doses of MFH were added. Adsorption followed by coagulation experiments were executed by adding a certain dosage of coagulants with mixing stirring similar to coagulation experiments. Then, a sample was taken using the same procedure [38].

$1000 \mathrm{ml}$ of raw water was transferred into a beaker with a certain dosage of MFH. The process included $3 \mathrm{~min}$ of the rapid mix at $350 \mathrm{rpm}, 30 \mathrm{~min}$ of slow mixing at $60 \mathrm{rpm}$ for flocculation, and $30 \mathrm{~min}$ for settling. Adsorption experiments were executed by mixing MFH with raw water using a magnetic stirrer at $150 \mathrm{rpm}$ for $120 \mathrm{~min}$ without heat. Subsequently, MFH was removed by filtration through a what man filter paper grad 1 (pore size of $0.6 \mu \mathrm{m}$ ) for measurements.

\section{TABLE. 3}

OPERATIONAL CONDITIONS OF COAGULATION/FLOCCULATION AND SEDIMENTATION PROCESS FOR POINT 3,4 - RMV: RAPID MIXING VELOCITY; RMT: RAPID MIXING TIMES; SMV: SLOW MIXING VELOCITY; SMT: SLOW MIXING TIMES; ST: SEDIMENTATION TIMES.

\begin{tabular}{c||c||c||c||c||c||c} 
ASSAY & $\mathbf{1}$ & $\mathbf{2}$ & $\mathbf{3}$ & $\mathbf{4}$ & $\mathbf{5}$ & $\mathbf{6}$ \\
\hline$R M V(r p m)$ & 200 & 300 & 350 & 250 & 300 & 350 \\
\hline$R M T(\mathrm{~min})$ & 1 & 1 & 1 & 3 & 3 & 3 \\
\hline$S M V(\mathrm{rpm})$ & 60 & 60 & 60 & 60 & 60 & 60 \\
\hline$S M T(\mathrm{~min})$ & 15 & 20 & 30 & 15 & 20 & 30 \\
\hline$S T$ (min) & 15 & 15 & 15 & 30 & 30 & 30
\end{tabular}

\section{Preparation of flaxseed husk ash (FHA)}

\section{A. Preparation of flaxseed husk ash (FHA)}

C. The sample of by-product flaxseed oil removal was dried in direct sunlight for one week, then washed with distilled water, dried, ground and taken to burn at $75,100,150$ and $200{ }^{\circ} \mathrm{C}$ for 2 hours.
B. Experimental procedure and the analytical measurements of (FHA)

Adsorption experiment was carried out by agitating FHA with raw water at the room temperature in a stirrer operating at $300 \mathrm{rpm}$ for certain time at a different dose of FHA having different concentrations of Fe. Subsequently, FHA was removed by filtration through a Whatman filter paper grad1 (pore size of $0.6 \mu \mathrm{m}$ ) for measurements, according to [39,40] with modification.

\section{Results and discussion}

\section{A. Characterization of the flaxseed husk (FH)}

The specific surface area of $\mathrm{FH}$ was $125.18 \mathrm{~m}^{2} / \mathrm{g}$. The average pore diameter of $\mathrm{FH}$ was $26.28 \mu \mathrm{m}$ indicating reasonable adsorption capacity [41].

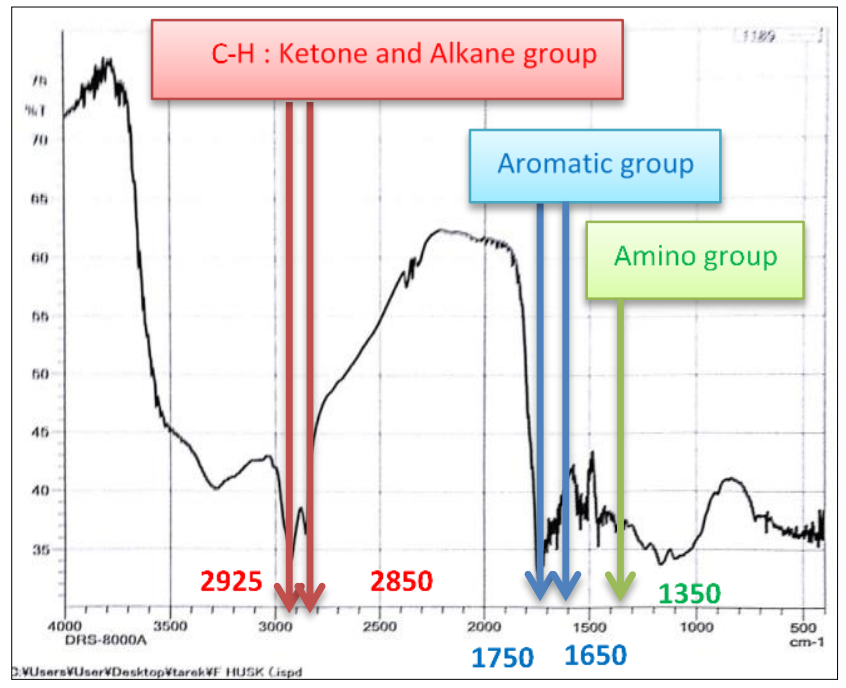

Fig. 1. The FTIR analysis of FH

Fig. 1. shows the functional groups which were done by FTIR spectrometry test, detected by the band intensity. Ketone and alkane groups $(\mathrm{C}-\mathrm{H})$ are at band intensity $2850 \mathrm{~cm}^{-1}$ and $2925 \mathrm{~cm}^{-1}$, and aromatic cyclic groups are at band intensity $1650 \mathrm{~cm}^{-1}$ and $1750 \mathrm{~cm}^{-1}$. The intense vibration at $1350 \mathrm{~cm}^{-1}$ gives evidence of a large number of amino groups in flaxseed husk (FH) structure [38].

\section{B. Characterization of the (FHA)}

Fig. 2. shows the functional groups which were done by FTIR Fourier transform infrared spectrometry analysis point out several main peaks at 3420, 2920, 1750 and $1170 \mathrm{~cm}-1$ were associated with -OH groups, - $\mathrm{CH}, \mathrm{C} \mathrm{O}$ bands and -OCH3 groups [42]. The presence of these active groups on the surface of flax seeds indicates their participation in the removal and absorption of iron from drinking water. 


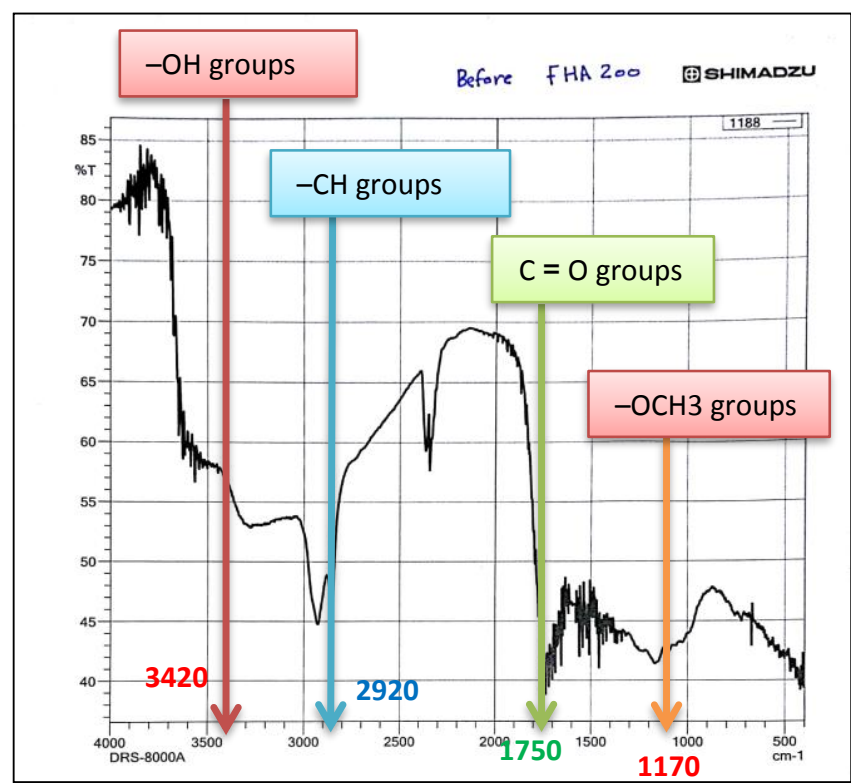

Fig. 2. FTIR spectra of fresh FHA200

\section{Removal of Turbidity and NOM}

\section{1) Effect of different concentration of AS / FH-OUTM, O}

The removal efficacies of turbidity and NOM at different percentages of AS / FH- OUT higher percentage of AS leads to a better turbidity removal due to the abundance of dissolved positively charged aluminum ions which neutralize the suspended particulates and increase the potential of agglomeration and floc formation [43]. On the other hand, the optimal ratio of $\left(\mathrm{AS} / \mathrm{FH}-\mathrm{OUT}_{\mathrm{M}, \mathrm{o}}\right)$ for NOM removal was (40/60) achieved a removal efficiency of $81 \%$. The higher percentage of AS leads to smaller surface area of coagulant/polymer which inhibit the adsorption of NOM on $\mathrm{FH}^{-O U T} \mathrm{~T}_{\mathrm{M}}$ o. In addition, the lower percentage of AS decreases the efficiency of agglomeration and precipitation of suspended particulates which reduces the NOM removal.

\section{2)Effect of slow mixing time}

The effect of slow mixing time on the removal of turbidity and NOM is shown in Fig. 4. It is clear that increasing the slow mixing time improved the removal of both turbidity and NOM. This improvement was achieved because the particles have adequate time to agglomerate and form stable flocs [44].

The maximum removal efficiency of turbidity was achieved after about 20 min of slow mixing, and additional time did not improve the removal of turbidity because the coagulant dose may be consumed at this stage and additional dosage may be required [45].

The optimum removal of NOM was achieved after $30 \mathrm{~min}$ of mixing, while additional time did not significantly improve the removal. Such a trend could be attributed to the consumption of aluminum ions and the occupation of all active sites on FH$\mathrm{OUT}_{\mathrm{M}}$, o surface [46]. Accordingly, the optimum slow mixing time is considered $30 \mathrm{~min}$ in this study. The adsorption of organic molecules may be attributed to the electrostatic attraction forces with amino groups of flaxseed husk which have been detected in FTIR spectra [47].

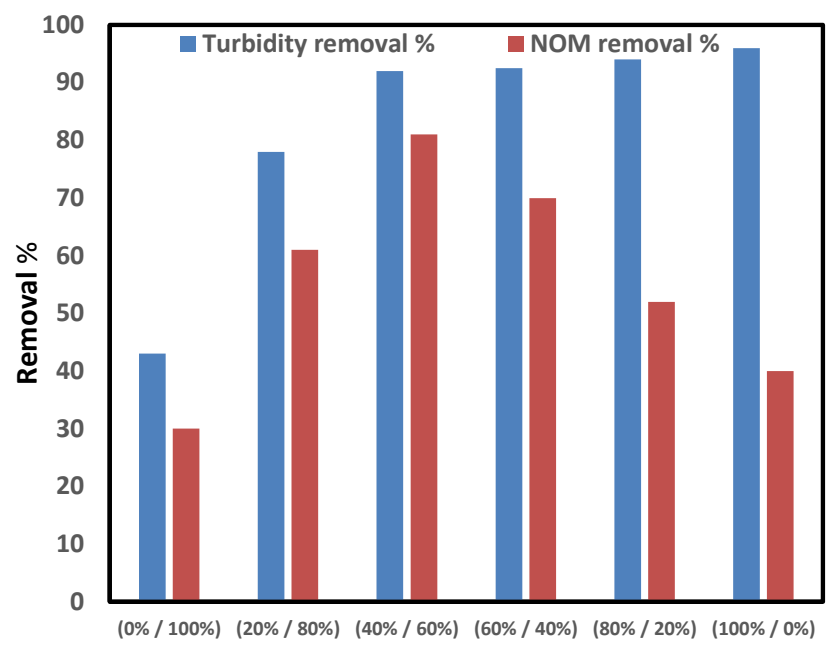

AS/FH-OUT

Fig. 3. Removal of turbidity and NOM using different ratios of (AS / FHOUT $_{\mathrm{M}, \mathrm{O}}$ ).

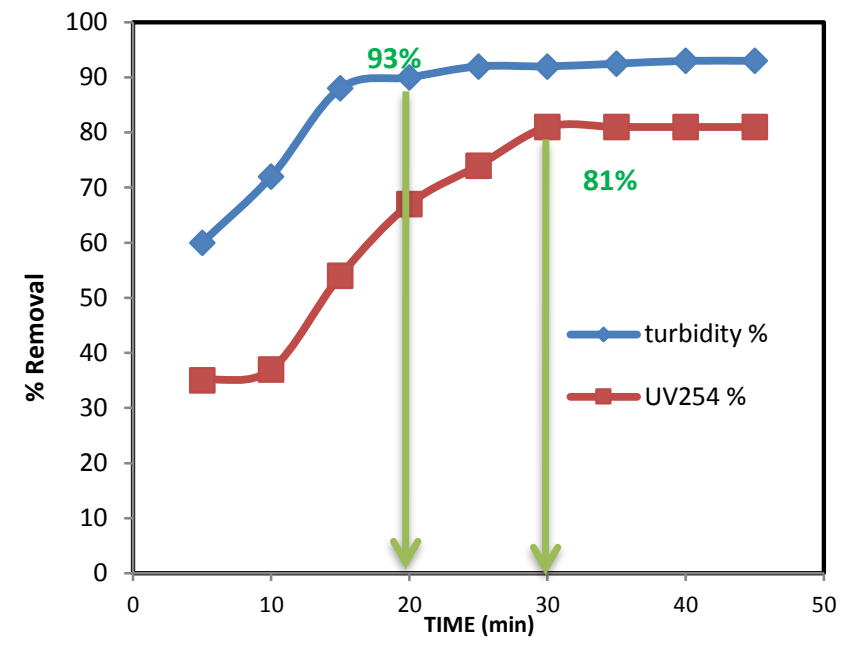

Fig. 4 . The effect of slow mixing time at optimal condition, initial turbidity $=9.0$ NTU, initial UV254 $=0.35 \mathrm{~cm}^{-1}$, and MFH: (40\% AS, 60\% FH-OUT $_{\mathrm{M}, \mathrm{o}}$ ).

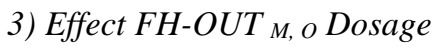

Different dosages of $\mathrm{FH}-\mathrm{OUT}_{\mathrm{M}}$, o were tested to investigate the optimum dosage for NOM and turbidity removal as shown in Fig. 5. It is clear that increasing the dosage of more than 40 mg. $\mathrm{l}^{-1}$ slightly improve both turbidity and NOM removal. This result is due to agglomeration of most of suspended particulates and/or adsorption of dissolved organic matter on MFH particles [48]. Accordingly, excess FH-OUT $_{M}$, o amount didn't achieve significantly efficiency improving.

\section{4)Effect of Initial NOM}

The removal efficiency of NOM at different initial concentrations was investigated and exhibited in Fig. 6. The removal efficiency results ranged from $98.4 \%$ to $100 \%$ using the optimum dosage of MFH. The removal efficiency was between $98.4 \%$ and $100 \%$ for initial concentration of UV254 between 0.05 to $0.18 \mathrm{~cm}^{-1}$, and between $98.4 \%$ and $99.3 \%$ for 
initial concentration of UV254 between 0.19 and $0.44 \mathrm{~cm}^{-1}$. The high removal efficiency was achieved due to the attractive of NOM functional groups for the high surface area of MFH which suggests a high adsorption capacity [49]. This finding indicates that the MFH could be used for removal of high concentration of NOM from water.

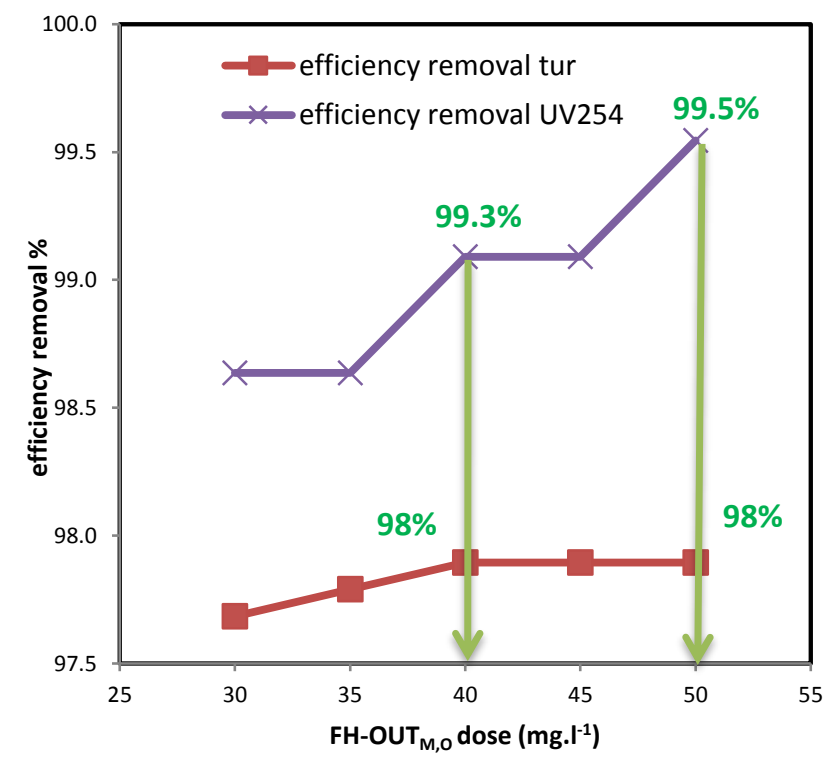

Fig. 5. The effect of different FH dose, initial turbidity $=9.5 \mathrm{NTU}$, initial $\mathrm{UV} 254=0.4 \mathrm{~cm}^{-1}$, and MFH: (40\% AS, variable FH-OUTM, O).

\section{Removal of Iron}

\section{1)Effect of FHA different types on iron removal $(\mathrm{Fe})$.}

Fig. 7 and table 4. show the effectiveness of FHA150 and FHA 200 on iron removal, which were $72 \%$ and $85 \%$ respectively. The removal process was accomplished by adding $250 \mathrm{mg}$ of FHA with $250 \mathrm{ml}$ of fresh raw water sample which was taken from EL Taleem well, after 30 min stirrer operating.

\section{2)Effect of FHA200 dosage.}

In order to study the effect of the burned dose on iron removal efficiency, doses ranging from 0.1 to $1 \mathrm{~g}$ and the concentration of iron in the raw water sample of the well 0.4 mg. $1^{-1}$ liter were used. The results of these experiments were represented in Fig. 8., and the different values were expressed. From Fig. 8. several conclusions can be read. At first: the removal efficiency was increased rapidly up to dose $0.4 \mathrm{~g}$, whereas the removal efficiency was increased slightly from dose $0.4 \mathrm{~g}$ to $0.75 \mathrm{~g}$ until reaches a roughly constant value begging from dose $0.75 \mathrm{~g}$ to $1 \mathrm{~g}$.

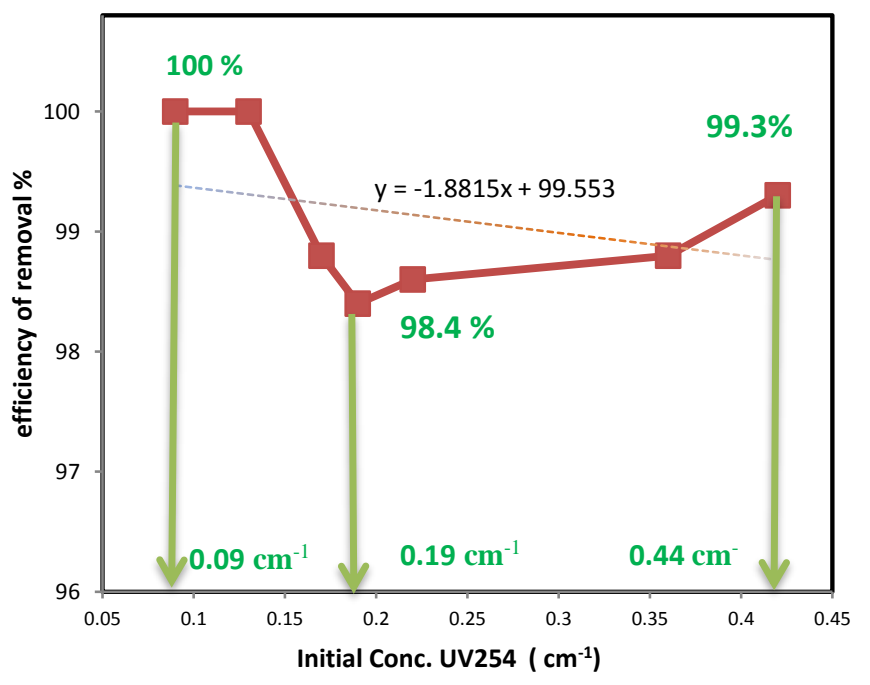

Fig. 6. The effect of different concentrations at optimal condition, MFH: (40\% AS 60\% FH-OUT M, O).

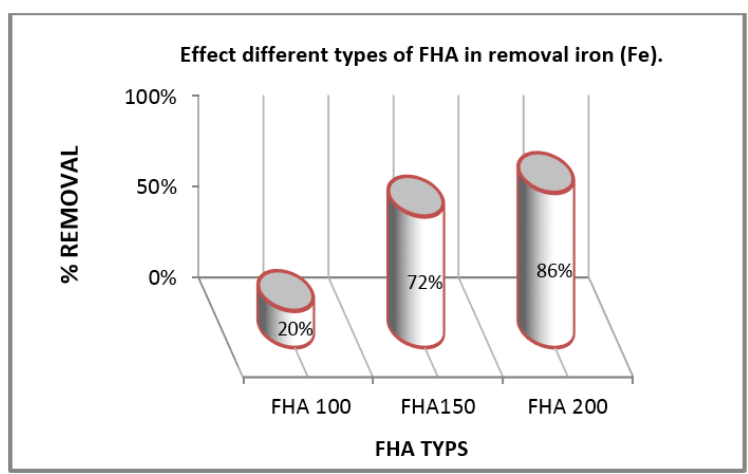

Fig. 7. Effect different types of FHA in removal iron (Fe).

TABLE. 4

EFFECT OF FHA TYPES IN REMOVAL IRON AFTER 30 MIN, TALEEM WELL $S_{\circ}(0.4) \mathrm{mg} . \mathrm{l}^{-1}$

\begin{tabular}{c||c||c||c||c} 
FHA & FHA 75 & FHA 100 & FHA150 & FHA 200 \\
\hline $\begin{array}{c}\text { Fe values } \\
\left(\text { mg. } l^{-1}\right)\end{array}$ & 0.49 & 0.32 & 0.11 & 0.06 \\
\hline$\%$ Removal & - & $20 \%$ & $72 \%$ & $86 \%$
\end{tabular}

This trend was expected due to the increased number of particles that have been absorbed with an increased dose of FHA200 which results in more iron attached to the surface area of FHA200. It has been observed that the largest removal efficiency is $90 \%$ starting from the dose $0.75 \mathrm{~g}$ of the burner (FHA200). Any other FHA200 dose was added more than 0.75-0.8 gm. $1^{-1}$ did not cause any significant change in removal efficiency.

\section{3) Effect of contact time.}

The efficiency of iron removal efficiency was measured, to samples of several concentrations which were taken from different wells. After studying the results shown in Fig. 9. specifically, from one minute to 60 minutes, it was founded a several explanations, at the beginning of contact, the rate of iron removal increased, which gradually decreased until it 
reached the stage of equilibrium, within 30 to 45 minutes. Hence, it noticed that the removal rate was become fixed from 45 minutes to 60 minutes of contact time, see Photo 1. and Photo 2. The efficiency of removal was found to be $89 \%$ to 90\% after 45 minutes of contact. This explains the efficiency of the active surface of the FHA, which can adsorb iron on the outside surface. Over time, the absorbed material was moved from the outer FHA surface to the inner surface result in adsorption of an additional amount of iron.

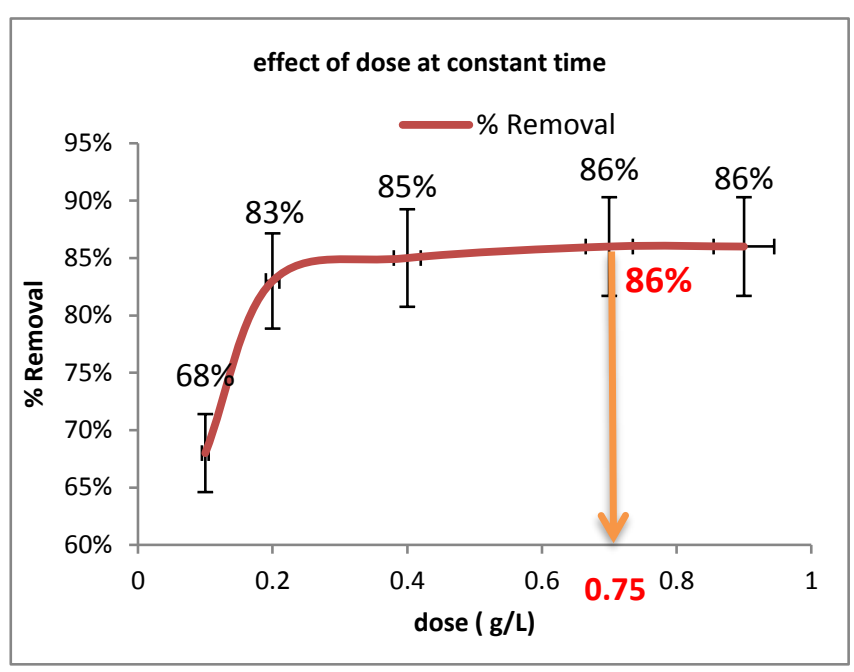

Fig. 8. Effect of FHA dosage on Efficiency of Fe Removal, CT=30 min

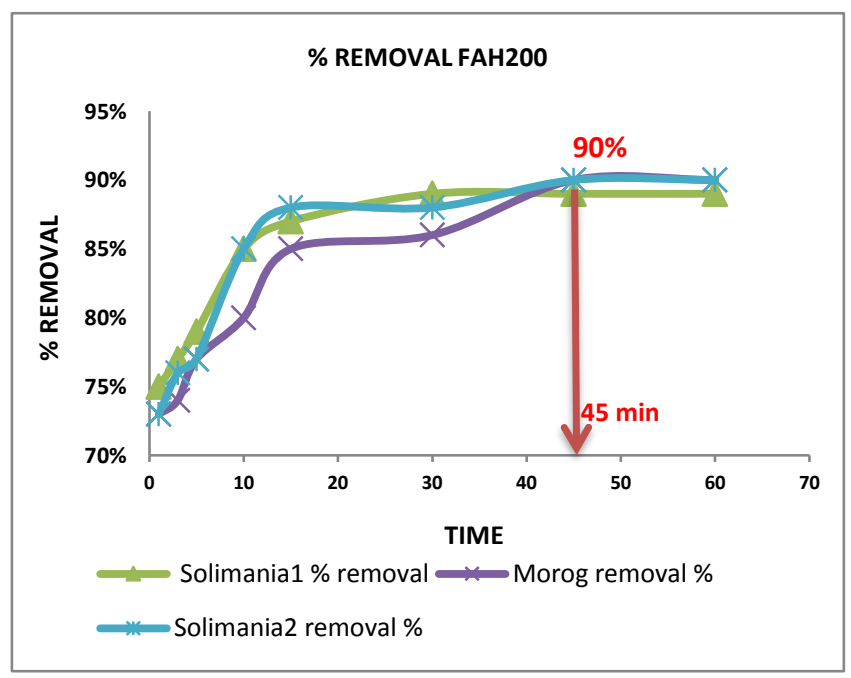

Fig. 9. Effect of contact time (CT) on iron removal by FHA200- (FHA dose $=0.75 \mathrm{~g} / \mathrm{L}$, initial Fe concentration $\left.=0.53-1.72 \mathrm{mg} . \mathrm{l}^{-1}\right)$.

\section{4) Effective of initial iron concentration}

The experiment was conducted at an initial iron concentration in raw water ranged from 0.13 to $1.72 \mathrm{mg}$ per liter. Photo 3. shows a sample used from Morog well at several iron concentration. It was found that the higher iron concentration, the greater removal efficiency.

Based on these results, can say that, the high initial concentration of iron in raw water enhances the absorption process and also enhances the interaction between the burner (FHA200) and the iron. It was also apparent that the removal efficiency has increased steadily in the low concentration of iron when comparing a several concentrations (from 0.13 to $0.72 \mathrm{mg} . \mathrm{l}^{-1}$ ). Whereas, in high iron concentrations (from 0.73 to $1.72 \mathrm{mg}^{-1} \mathrm{l}^{-1}$ ), the removal efficiency increases slightly. This was shown by comparing the slope of the imaginary straightline $\mathrm{AB}$ with the slope of the straight-line $\mathrm{BC}$ in Fig. 10. The Fe removal efficiency percentage was found about $72 \%$ for $0.13 \mathrm{mg} . \mathrm{l}^{-1} \mathrm{Fe}$ and $89 \%$ for $1.72 \mathrm{mg} . \mathrm{l}^{-1} \mathrm{Fe}$ after 30 minutes of contact time (CT).

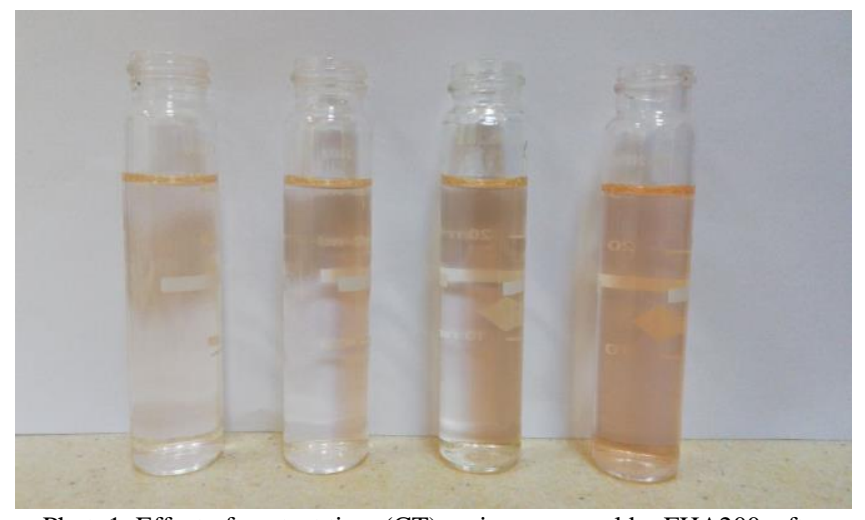

Photo1. Effect of contact time (CT) on iron removal by FHA200, after $15,30,45,60 \mathrm{~min}$

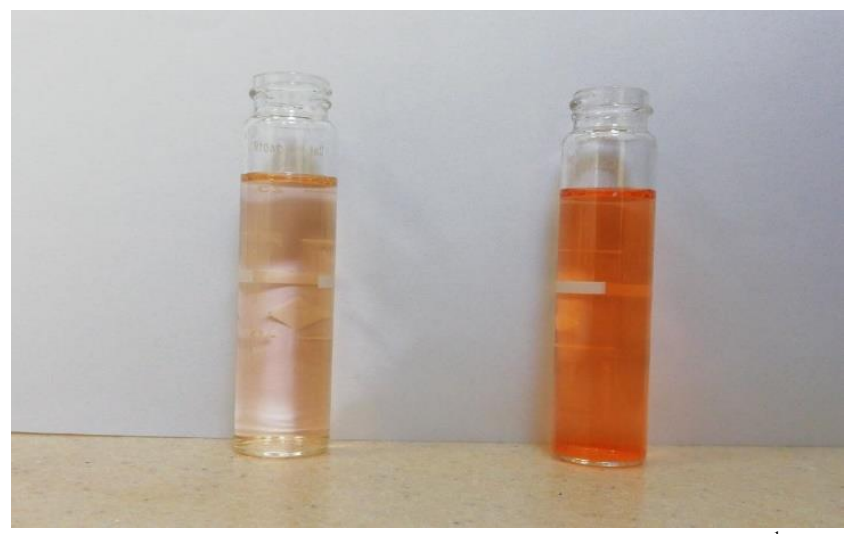

Photo2. Effect of contact time (CT): initial concentration1.72 mg..$^{-1}$ and after $60 \mathrm{~min}=0.1 \mathrm{mg} . \mathrm{l}^{-1}$

\section{E. Adsorption kinetics.}

Adsorption kinetics are one of the most important characteristics that determine adsorption efficiency on the surface of the adsorbent material, which describes the soluble absorption rate. Fe (II) adsorption kinetics were evaluated by applying two popular models: the pseudo- kinetics model of the first order [50] and the pseudo- kinetics model of the second order [51].

\section{1)The pseudo- kinetics model of first order}

The first pseudo-kinetic model assumes that the Fe (II) absorption rate with time is directly proportional to the number 
of active sites available on the surface of the adsorbents. The first pseudo-kinetic model is given to the equation as follow:

$\ln \left(\mathrm{qe}-\mathrm{q}_{\mathrm{t}}\right)=\ln \mathrm{q}_{\mathrm{e}}-\mathrm{k}_{1} \mathrm{t}$,

Where $\mathrm{q}_{\mathrm{e}}$ and $\mathrm{q}_{\mathrm{t}}$ represent the amount of absorption $(\mathrm{mg} / \mathrm{g})$ at equilibrium case and $\mathrm{t}$ (time) respectively, and $\mathrm{k}_{1}$ is the adsorption rate constant the pseudo- kinetics model of the first order $\left(\mathrm{min}^{-1}\right)$. The $\mathrm{k}_{1}$ values can be specified empirically by $\mathrm{ln}$ $\left(\mathrm{qe}-\mathrm{q}_{\mathrm{t}}\right)$ against $\mathrm{t}$.

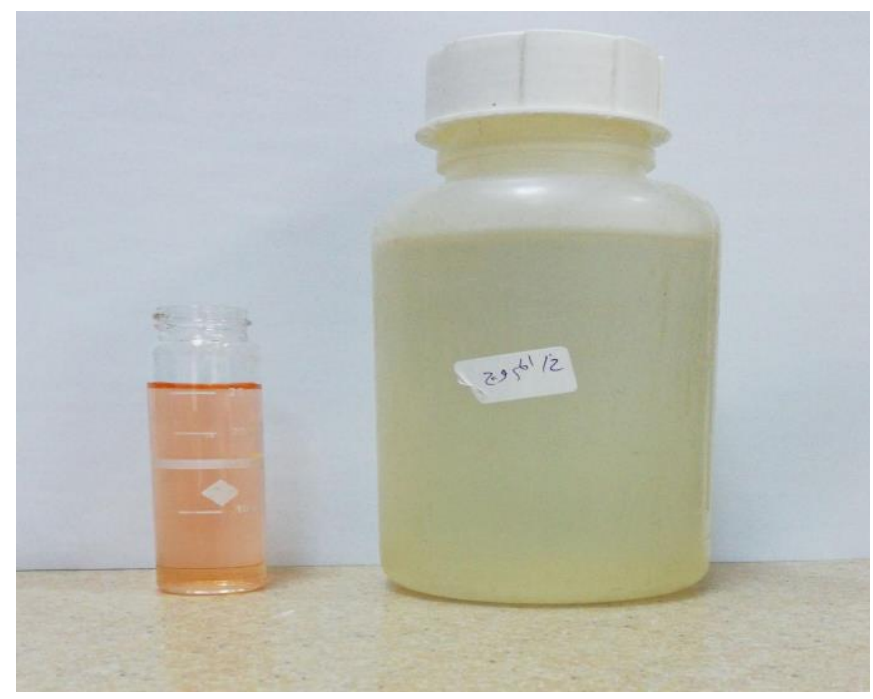

Photo 3. sample from Morog well $\mathrm{Fe}=0.4 \mathrm{mg} \cdot \mathrm{l}^{-1}$

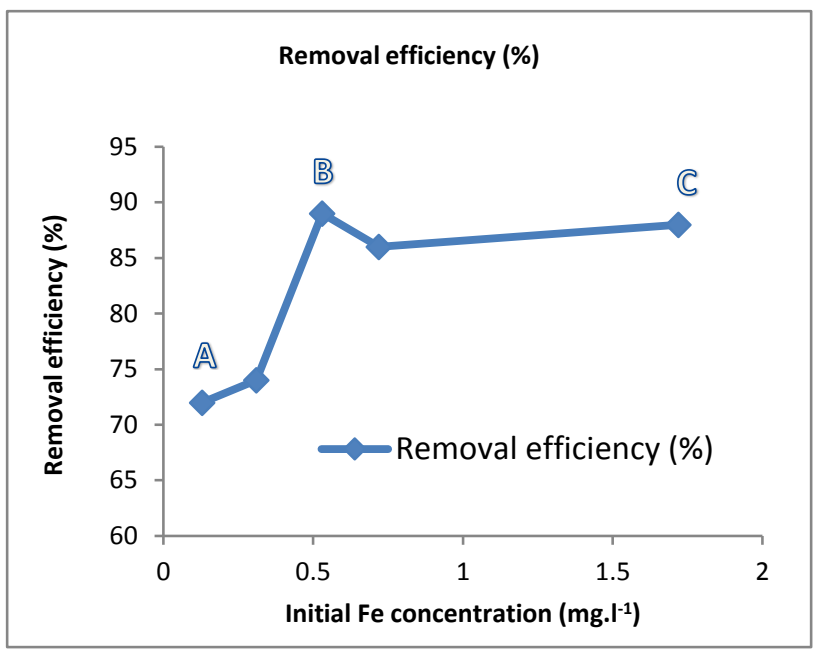

Fig. 10. Effect of initial concentration on the Fe removal by FHA200, (dose $=0.75 \mathrm{gm}$. per liter and $\mathrm{CT}=45 \mathrm{~min}$ )

Fig. 11 shows the linear segment of $\ln \left(\mathrm{qe}-\mathrm{q}_{\mathrm{t}}\right)$ versus the pseudo- kinetics model of the first order for the absorption of Fe (II) ions on the FHA. The correlation coefficients of adsorption using FHA for the pseudo- kinetics model of the first order $\left(R^{2}=0.7987\right)$ are closer to the unity.

\section{2) The pseudo- kinetics model of second order}

The pseudo- kinetics model of the second order assumes that chemical absorption represents the phase of limiting absorption rate, which involves the forces of equivalence by exchanging or transferring electrons between adsorbate and absorbent materials. pseudo- kinetics model of the second order equation is expressed as follow:

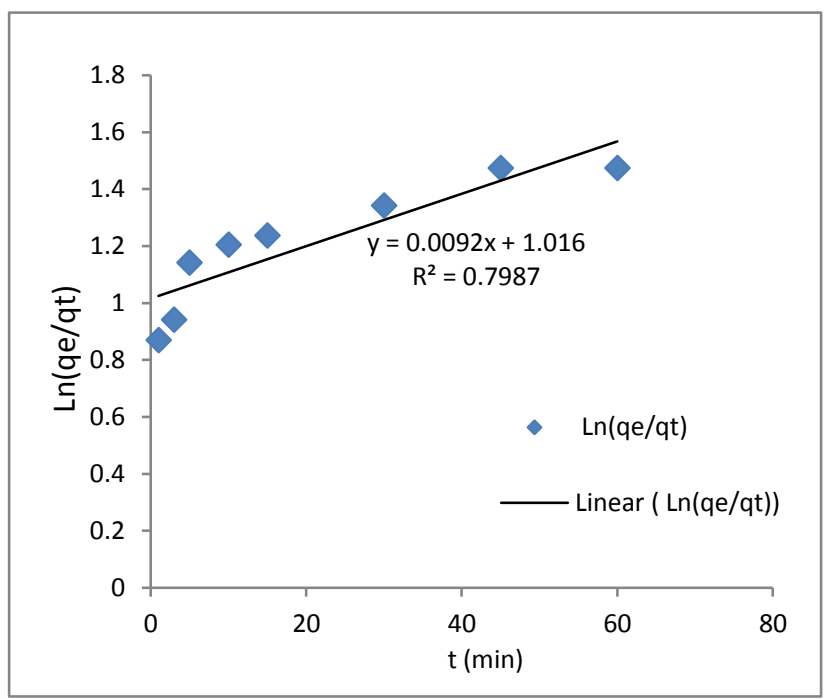

Fig. 11. pseudo-first-order kinetic plots on FHA200 for Fe (II) (metal concentration: $1.72 \mathrm{mg} . \mathrm{l}^{-1}$; adsorption dose: $0.1 \mathrm{~g} / 100 \mathrm{ml}$; contact time: 60 min; $\mathrm{pH}: 7.8$ ).

$t / q_{t}=1 /\left(k_{2} \cdot q_{e}^{2}\right)+\left(t / q_{e}\right)$

Where: $\mathrm{k}_{2}(\mathrm{~g} / \mathrm{mg} \mathrm{min})$ is the rate constant of the secondorder equation, qt $(\mathrm{mg} / \mathrm{g}$ ) is the absorption time $\mathrm{t}$ (time) amount and qe is the absorption equilibrium amount ( $\mathrm{mg} / \mathrm{g}$ ).

The results showed that the most suitable model for expressing the absorption rate of $\mathrm{Fe}$ (II) is the pseudo- kinetics model of the second order. The correlation coefficients of adsorption using FHA for the pseudo- kinetics model of the second order $\left(\mathrm{R}^{2}=0.9999\right)$ are closer to the unity than those for the pseudo- kinetics model of the first order. Fig. 12 shows the linear segment of $t / q_{\mathrm{e}}$ versus the pseudo- kinetics model of the second order for the absorption of Fe (II) ions on the FHA. The theoretical $\mathrm{q}_{\mathrm{e}}$ values of the FHA correspond well to the experimental values as compared to those of the pseudokinetic model of the first order. While the theoretical values of the absorption of flaxseed husk for both ends of the two movements are well correlated with the experimental qe values, kinetic models are well suited to the absorption process and $\mathrm{Fe}$ (II) chemisorption assay emphasizes by flaxseed husks.

\section{F. Adsorption isotherm studies}

The adsorption process is described by Adsorption isotherms and also describe the interaction between adsorbates and bio-sorbent. For analysis and design of adsorption systems 
must establish the most acceptable correlations for the batch equilibrium data, or at equilibrium solution and constant temperature, the Adsorption isotherms used to describe the correlation between the number of species/ions adsorbed onto the solid phase.

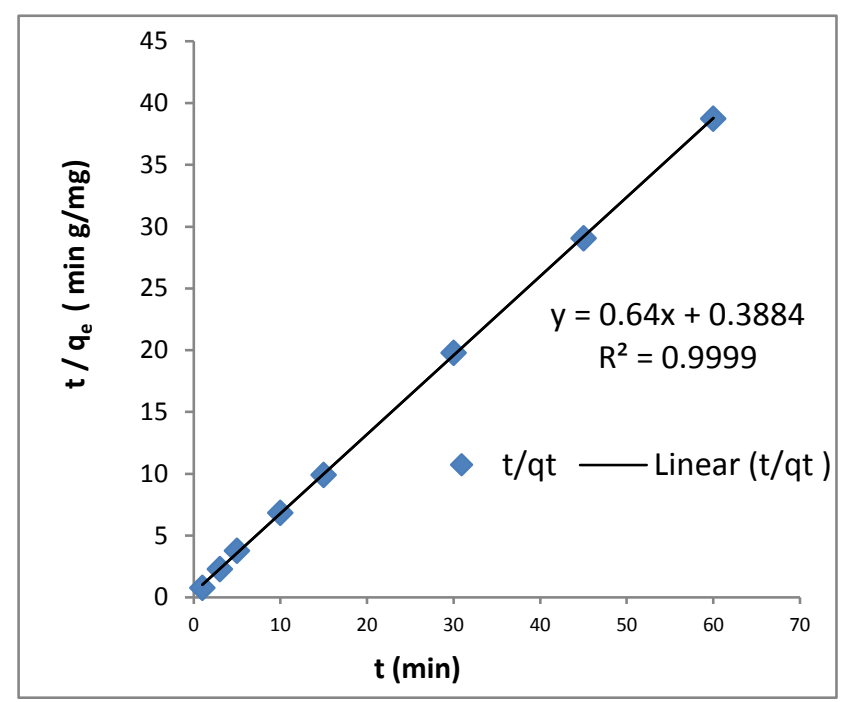

Fig. 12. Pseudo-second-order kinetic plots onto FHA200 for Fe (II) biosorption (metal concentration: $1.72 \mathrm{mg} .1^{-1}$, adsorbent dosage: $0.1 \mathrm{~g} / 100 \mathrm{~mL}$; contact time: $60 \mathrm{~min}$; $\mathrm{pH}: 7.8$ )

Langmuir and Freundlich models are the most frequently used models to describe the equilibrium data of adsorption. in this paper, applied the two model Langmuir and Freundlich in section 8 and 9 to study adsorption isotherm system as following down [52].

\section{1) Langmuir isotherm}

This model assumes that absorption occurs on a homogeneous surface of the adsorbent without any interaction between adsorbed ions and assumes that the absorptive sites are equal in size and shape, i.e., identical, this absorption is monolayer. During the adsorption process a constant amount of heat energy is released as the number of vacant sites is constant $[53,54]$. The following equation expresses the nonlinear form of the Langmuir model:

$$
C_{e} / q e=\left(1 / q_{m} K_{L}\right)+\left(C_{e} / q_{m}\right)
$$

Where: $\mathrm{k}_{\mathrm{L}}$ is a constant that expresses the Convergence of the obligated sites towards the adsorbent, called the Langmuir constant $\left(\mathrm{L} \mathrm{mg}^{-1}\right), \mathrm{q}_{\mathrm{m}}$ known as the monolayer uptake capacity or the quantity of absorbed pores per unit mass of adsorbents that form a complete monolayer on the outward surface (mg.g $\left.{ }^{1}\right), \mathrm{q}_{\mathrm{e}}$ is equilibrium concentration of $\mathrm{Fe}$ (II) on the bio-sorbent (mg. $\mathrm{g}^{-1}$ ) and $\mathrm{C}_{\mathrm{e}}$ is the concentration of adsorbed substance at equilibrium or adsorbate concentration $\left(\mathrm{mg} . \mathrm{l}^{-1}\right)$.

Langmuir isotherm plots for the bio-sorption of $\mathrm{Fe}$ (II) showed in Fig. 13. which demonstrate the degradation plot of $\mathrm{C}_{\mathrm{e}} / \mathrm{q}_{\mathrm{e}}$ versus $\mathrm{C}_{\mathrm{e}}$. the Langmuir isotherm curve shows $\mathrm{R} 2$ :
0,998 which represent a high coefficient of sorption determination data which used to describe the adsorption isotherm of iron onto FHA, this value points out the adsorption equilibrium constant (R) was suitable for describing the adsorption isotherm. observed that, there was not interaction happened between the adsorbed Fe molecules, and the uptake positions formed a homogenous distribution. the monolayer converged by adsorbed iron at the outer surface of FHA was $6.2 \mathrm{mg}$. $\mathrm{g}^{-1}$.

To represent the type of Langmuir isotherm, proposed the separation factor (RL) showed in equation 4.

$\mathrm{R}_{\mathrm{L}}=1 /\left(1+\mathrm{K}_{\mathrm{L}} \mathrm{C}_{\mathrm{o}}\right)$

where, $\mathrm{RL}$ is a factor describing the isotherm shape called separation factor. according to the $\mathrm{R}_{\mathrm{L}}$ value, the shape of Langmuir isotherm could be determined. AT $R_{L}=1$ means linear isotherm, at $R_{L}=0$ means irreversible, $R_{L}$ between 0 and 1 means favorable isotherm and unfavorable at $R_{L}>1$. In this study $R_{L}$ value indicating that favorable adsorption of iron into FHA.

\section{2)Freundlich isotherm}

Freundlich model differs from Langmuir's predecessor in that it is an empirical model used to describe the process of heterogeneous adsorption (heterogeneous adsorption surface and active sites with different energies) [55,56].

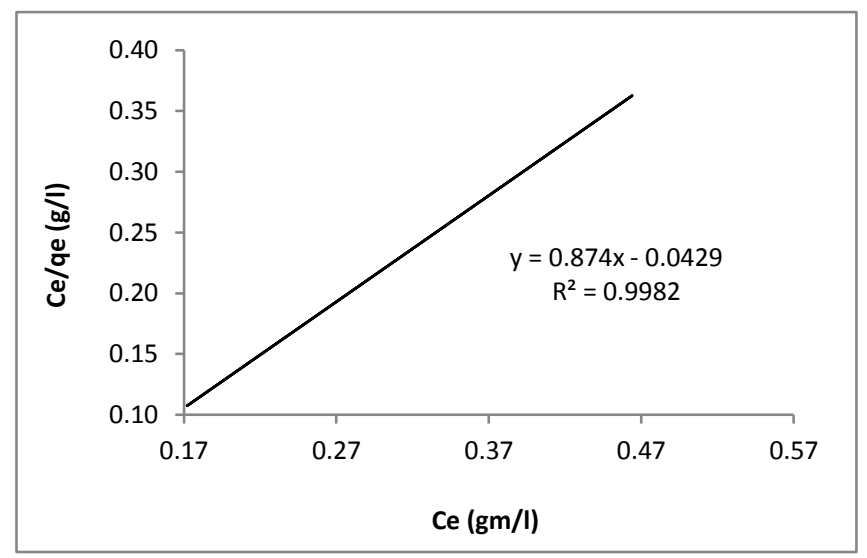

Fig. 13. Langmuir isotherm plots for the bio-sorption of Fe(II) onto FHA200 (adsorbent dosage: $0.1 \mathrm{~g} / 100 \mathrm{~mL}$; contact time: $45 \mathrm{~min}$; pH: 7.8

It can be expressed in the following equation:

$\mathrm{q}_{\mathrm{e}}=\mathrm{K}_{\mathbf{f}} * \mathrm{C}_{\mathrm{e}}{ }^{1 / n}$

The linearized logarithmic form of the equation is

$\ln \left(\mathrm{q}_{\mathrm{e}}\right)=\ln \left(\mathrm{K}_{\mathrm{F}}\right)+1 / \mathrm{n} \ln \left(\mathrm{C}_{\mathrm{e}}\right)$

where $\mathrm{K}_{\mathrm{F}}$ is Freundlich distribution coefficient or Freundlich constant, represent uptake capacity of iron onto FHA ((mg. $\left.\left.\mathrm{g}^{-1}\right)\left(\mathrm{L}_{\mathrm{mg}} \mathrm{mg}^{-1}\right) 1 / \mathrm{n}\right)$. Can express about uptake intensity by empirical coefficient $1 / \mathrm{n}$, according to the $1 / \mathrm{n}$ value, can determine the favorability of adsorption. At $1 / n$ 
between 0 and 1 means favorable isotherm, at $1 / \mathrm{n}=0$ means irreversible, at $1 / \mathrm{n}>1$ means unfavorable uptake. the smaller value of $1 / \mathrm{n}$ means stronger interaction occurs between FHA and iron [57].

A Freundlich regression plot of $\ln \left(\mathrm{q}_{\mathrm{e}}\right)$ versus $\ln \left(\mathrm{C}_{\mathrm{e}}\right)$ is shown in Fig. 14. in which the slope of the line $(1 / \mathrm{n})$ and the other value associated with it $\left(\mathrm{K}_{\mathrm{F}}\right)$ is shown. From the figure it turns out that the slope value is 0.264 less than the correct one, so the absorption is classified as preferred (favorable isotherm). The slope value $(1 / \mathrm{n})$ also illustrates several considerations: $26.4 \%$ of the active adsorption sites retained the same energy level [58], and the smaller the slope value, the more effective the adsorption, the higher the adsorption strength and the heterogeneity of hard surfaces as well. [59]

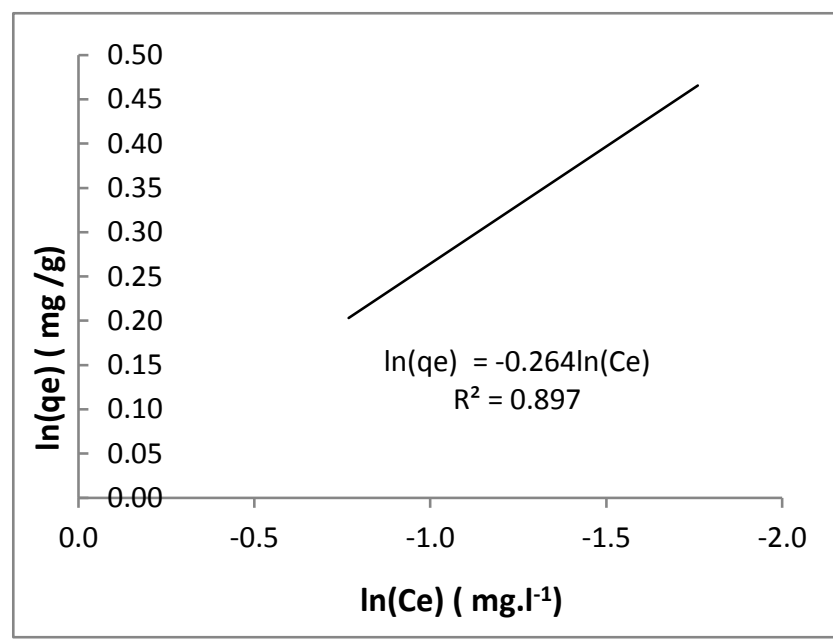

Fig. 14. Freundlich isotherm plots for the bio-sorption of $\mathrm{Fe}(\mathrm{II})$ onto FHA200 adsorbent dosage: $0.1 \mathrm{~g} / 100 \mathrm{~mL}$; contact time: $45 \mathrm{~min}$; $\mathrm{pH}: 7.8$

\section{G. Comparison study}

The (Table 5) gives a comparison between metal ions sorbents, including iron, in terms of adsorption capacity, contact time, dissolved ions concentration and temperature rang [60].

The table gives different and varied indicators on the capacity of adsorbents according to the type of adsorbent and metal ions concentration in the aqueous solution. The adsorption capacity depends on the adsorbent dosage, the physical and chemical composition of the adsorbent. This topic was discussed during the FTIR analysis of flaxseed husk ash. From above table, it is also evident that the flaxseed husk ash has a similar absorption capacity compare with other sorbents mentioned in the attached references. [60].

\section{Conclusion}

flaxseed husk was modified and used for removal of turbidity and NOM from drinking water. The characterization of FH reveals high adsorption capacity due to the high surface area and the existence of a large number of amino groups.
TABLE. 5

COMPARISON OF MAXIMUM ADSORPTION CAPACITIES OF DIFFERENT ADSORBENTS FOR FE (II) IONS.

\begin{tabular}{|c|c|c|c|c|c|c|}
\hline No & $\begin{array}{r}\text { Adsorbe } \\
\text { nts }\end{array}$ & $\begin{array}{r}\text { Adsorption } \\
\text { capacity } \\
(\mathbf{m g} / \mathbf{g})\end{array}$ & $\begin{array}{r}\text { Contact } \\
\text { time } \\
(\text { min })\end{array}$ & $\begin{array}{c}\text { Concen } \\
\text { tration } \\
\text { range } \\
\left(\mathrm{mg} . \mathrm{l}^{-1}\right)\end{array}$ & $\begin{array}{r}\text { Temp. } \\
\text { range } \\
(\mathbf{K})\end{array}$ & Ref. \\
\hline 1 & $\begin{array}{l}\text { Cross- } \\
\text { linked } \\
\text { chitosan }\end{array}$ & 64.1 & 60 & $3-9$ & - & [61] \\
\hline 2 & Chitosan & 57.5 & 40 & $3-9$ & - & [61] \\
\hline 3 & $\begin{array}{l}\text { Modifie } \\
\mathrm{d} \text { coir } \\
\text { fibres }\end{array}$ & 7.49 & 120 & $\begin{array}{l}73.50- \\
83.9\end{array}$ & 308 & [62] \\
\hline 4 & $\begin{array}{l}\text { Rice } \\
\text { husk ash }\end{array}$ & 6.21 & 60 & $2-40$ & 298 & [63] \\
\hline 5 & $\begin{array}{l}\text { Flaxseed } \\
\text { husk ash }\end{array}$ & 6.19 & 45 & $\begin{array}{l}0.4- \\
1.72 \\
\end{array}$ & 296 & $\begin{array}{l}\text { Present } \\
\text { study }\end{array}$ \\
\hline 6 & $\begin{array}{l}\text { Coir } \\
\text { fibres }\end{array}$ & 2.84 & 120 & $\begin{array}{l}73.50- \\
83.9 \\
\end{array}$ & 308 & [62] \\
\hline 7 & $\begin{array}{l}\text { Pine } \\
\text { bark } \\
\text { wastes }\end{array}$ & 2.03 & 30 & $\begin{array}{l}55.6- \\
111.2\end{array}$ & $\begin{array}{l}303- \\
333\end{array}$ & [64] \\
\hline
\end{tabular}

The optimal ratio of (AS / FH-OUT $\mathrm{M}_{\mathrm{M}} \mathrm{o}$ ) for removing both NOM and turbidity was (40\% / 80\%). The removal efficiency for NOM and turbidity at ratio $(40 \% / 60 \%)$ was $81 \%$ and $93 \%$. Increasing the dosage of $\mathrm{MFH}$ to $(40 \% / 80 \%)$, significantly improved the removal efficiency to $98.0 \%$ for turbidity and $99.3 \%$ for NOM. Moreover, the MFH revealed a high removal efficiency at a higher initial NOM value which suggests the favorability for treatment of raw water contaminated with NOM.

In this study, many experiments have been carried out to investigate the performance of FHA to remove iron from aqueous solutions under various operational conditions. The removed iron by flaxseed husk ash was found to be depending on different types of FHA, Initial iron concentration, contact time, and dosage of the FHA. The initial $\mathrm{pH}$ values ranged between 7.0 to 7.8 , Which did not cause any significant change in the $\mathrm{pH}$ after adding of the FHA200. It may be noted that the efficiency of de-iron removal of water solution is directly proportional to increase of adsorbent material, initial iron concentration and contact time. Maximum removal efficiency of $86-90 \%$ was observed at adsorbent dosage 0.75 gm. l $^{-1}$. The FTIR spectra of FHA shows effective groups on the surface of FHA involved in iron removal from drinking water. Adsorption kinetics was used to analyze the equilibrium data. The experimental data of biosorption isotherms for the biosorbent yielded fitted well with the kinetics order, the pseudo- kinetics model of the first order and the pseudokinetics model of the second order. The results of the adsorption equilibrium by Langmuir and Freundlich model showed FHA's ability to absorb iron ions at a high degree, hence, this was expressed in favorable. On the other hand, the correlation coefficient of the Langmuir and Freundlich models were 0.998 and 0.897 , respectively, shows that the relationship between the absorbed iron ions and the FHA concentration in this study with the Langmuir model is better than that of the Freundlich model because the correlation coefficient in the 
Langmuir model is greater than the correlation coefficient in the Freundlich model.

\section{REFERENCES}

[1]. T. K. Trinh and L. S. Kang, (2011) Response surface methodological approach to optimize the coagulation-flocculation process in drinking water treatment, Chem. Eng. Res., Des. vol. 89, no. 7, pp. 1126-1135.

[2]. P. C. Singer, (1994) Control of disinfection by-products in drinking water, J. Environ. Eng., Vol. 120, no. 4, pp. 727-744.

[3]. M. H. Cho, C. H. Lee, and S. Lee, Effect of flocculation conditions on membrane permeability in coagulation-microfiltration, Desalination, Vol. 191, no. (1-3), pp. 386-396, 2006.

[4]. G. Hua and D. A. Reckhow, (2007) Comparison of disinfection byproduct formation from chlorine and alternative disinfectants, Water Res., Vol. 41, no. 8, pp. 1667-1678.

[5]. A. Ashery, K. Radwan and M. Gar Alalm, (2010) The effect of pH control on turbidity and NOM removal in conventional water treatment," Int. Water Technol. J., vol. 1, no. 2, pp. 1-16.

[6]. W. Chu, D. Yao, N. Gao, T. Bond and M. R. Templeton, (2015) The enhanced removal of carbonaceous and nitrogenous disinfection byproduct precursors using integrated permanganate oxidation and powdered activated carbon adsorption pretreatment, Chemosphere, vol. 141, pp. 1-6.

[7]. M. Yan, D. Wang, J. Ni, J. Qu, W. Ni and J. Van Leeuwen, (2009) Natural organic matter (NOM) removal in a typical North-China water plant by enhanced coagulation: Targets and techniques, Sep. Purif. Technol., vol. 68, no. 3, pp. 320-327.

[8]. T. Leiknes, H. Ødegaard and H. Myklebust, (2004) Removal of natural organic matter (NOM) in drinking water treatment by coagulationmicrofiltration using metal membranes, J. Memb. Sci. 242 (1-2): 47-55.

[9]. M. Gar Alalm, A. Tawfik, and S. Ookawara, (2015) Combined Solar advanced oxidation and PAC adsorption for removal of pesticides from industrial wastewater, J. Mater. Environ. Sci. 6 (3): 800-809.

[10]. M. Gar Alalm, A. Tawfik, and S. Ookawara, (2016) Enhancement of photocatalytic activity of $\mathrm{TiO} 2$ by immobilization on activated carbon for degradation of pharmaceuticals, J. Environ. Chem. Eng. 4 (2): 19291937.

[11]. M. Gar Alalm, S. Ookawara, D. Fukushi, A. Sato, and A. Tawfik, (2016) Improved WO 3 photocatalytic efficiency using $\mathrm{ZrO} 2$ and $\mathrm{Ru}$ for the degradation of carbofuran and ampicillin, J. Hazard. Mater. $302225-$ 231.

[12]. M. Gar Alalm, A. Tawfik, S. Ookawara, (2014) Investigation of optimum conditions and costs estimation for degradation of phenol by solar photo-Fenton process, Appl. Water Sci.

[13]. T. Robinson, B. Chandran, P. Nigam, (2002) Removal of dyes from a synthetic textile dye effluent by biosorption on apple pomace and wheat straw, Water Res. 36 (11): 2824-2830.

[14]. A. Gupta, S.R. Vidyarthi, N. Sankarakrishnan, (2015) Concurrent removal of As (III) and As (V) using green low cost functionalized biosorbent - Saccharum officinarum bagasse, J. Environ. Chem. Eng. 3 (1): 113-121.

[15]. Ş. Taşar, F. Kaya, A. Özer, (2014) Biosorption of lead (II) ions from aqueous solution by peanut shells: Equilibrium, thermodynamic and kinetic studies, J. Environ. Chem. Eng. 2 (2): 1018-1026.

[16]. A. Saeed, M. Iqbal, (2003) Bioremoval of cadmium from aqueous solution by black gram husk (Cicer arientinum), Water Res. 37 (14): $3472-3480$.

[17]. A. H. Khan, S. Ahmad, A. Ahmad, (1998) Role of Sawdust in the Removal of Copper (II) From Industrial Wastes, Water Res. 32 (10): 3085-3091.

[18]. C. Namasivayam, D. Prabha, M. Kumutha, (1998) Removal of direct red and acid brilliant blue by adsorption on to banana pith, Bioresour. Technol. 64 (1): 77-79.

[19]. http://www.aleqt.com/2015/08/02/article_978203.html

[20]. http://www.ngwa.org/Fundamentals/teachers/Pages/information-onearth-water.aspx

[21]. http://www.ordemengenheiros.pt/fotos/editor2/areainternacional/201509 24.pdf, "Water supply and sanitation in Saudi Arabia Source: updated in March 2015"

[22]. https://en.wikipedia.org/wiki/Water_supply_and_sanitation_in_Saudi_Ar abia? oldid $=672037079$

[23]. B. Renata, K. Tomáś, (2016) Efficacy of sorption materials for nickel, iron and manganese removal from water, International Conference on
Efficient \& Sustainable Water Systems Management toward Worth Living Development, 2nd EWaS, Procedia Engineering 16256 - 63

[24]. J. Ilavský, D. Barloková, K. Munka, (2015) Antimony removal from water by adsorption to iron-based sorption materials, Water Air Soil Pollut. 226:1 1-8.

[25]. Gulf Standard Specification for Unsaturated Drinking Water No. 149 / 2000

[26]. Journal of King Abdulaziz University: Engineering Sciences, vol. 14, No. 2, (2002), pp. 81-104

[27]. Water quality standards, Presidency of Meteorology and Environmental (PME), Saudi Arabia

[28]. GCC STANDARDIZATION ORGANIZATION (GSO), GSO5/ FDS / 2012, Bottled drinking water

[29]. D. Barloková, J. Ilavský, (2010) Removal of Iron and Manganese from Water Using Filtration by Natural Materials, Polish J. of Environ. Stud. Vol. 19, No. 6, 1117-1122

[30]. http://www.pbwatersoftening.com/5-harmful-effects-high-levels-ironwater/

[31]. Iron in Drinking-water, background document for development of WHO Guidelines for Drinking water Quality, http://www.who.int/water_sanitation_health/dwq/chemicals/iron.pdf, 2003

[32]. M. Tehrani, R. Batal, M. Kamalinejad, A. Mahbubi, (2014) Extraction and purification of flaxseed proteins and studying their antibacterial activities. J Plant Sci 2(1): 70-76.

[33]. A. Baghvand, N. Mehrdadi and A. Karbassi, Optimizing coagulation process for low to high turbidity waters using aluminum and iron salts, American Journal of Environmental Sciences, vol.6, No.5, pp.442448,2010

[34]. H. Makki, A. Al-Alawy, N. Abdul-Razaq and M. Mohammed, (2010) Using Aluminum Refuse as a Coagulant in the Coagulation and Flocculation Processes, Iraqi Journal of Chemical and Petroleum Engineering, vol. 11, no. 3, pp. 15-22.

[35]. R. Joshua and V. Vasu, (2013) Characteristics of Stored Rain Water and its Treatment Technology Using Moringa seeds, International J ournal of Life science and Pharma Research, vol. 2, no. 1, pp. 154-175.

[36]. G. Madrona, I. Branco, V. Seolin, B. Filho, M. Fagundes-Klen, and R. Bergamasco, (2012) Evaluation of extracts of moringa oleifera lam seeds obtained with $\mathrm{NaCl}$ and their effects on watert reatment, Acta Scientiarum-Technology, vol. 34, no. 3, pp. 289-293.

[37]. K. Cordeiro R. Cardoso, E. Bergamasco, S. Cossich, and L. Moraes, optimizing mixture and decantation times in the process of coagulation/flocculation of raw water using Moringa oleifera Lam, (2008) Acta Scientiarum. Technology, vol. 30, no. 2.

[38]. X. Zhan, B. Gao, Q. Yue, B. Liu, X. Xu and Q. Li, Removal natural organic matter by coagulation-adsorption and evaluating the serial effect through a chlorine decay model, Journal of Hazardous Materials 183 (2010) 279-286.

[39]. APHA, (2005) Standard Methods for the Examination of Water and Wastewater, American Public Health Association, Washington DC.

[40]. G. Qian et al., (2014) Removal of $\mathrm{Fe}^{+}$from Aqueous Solution by Natural Apatite, Journal of Surface Engineered Materials and Advanced Technology, 4, 14-20

[41]. G. Jain, et al., (2010) Heat Shock Proteins and Plants book, chapter 5: $106-132$.

[42]. M. Tehrani, R. Batal, M. Kamalinejad, A. Mahbubi, (2014) Extraction and Purification of Flaxseed Proteins and Studying their Antibacterial Activities. Journal of Plant Sciences. Vol. 2, No. 1, pp. 70-76.

[43]. A. Ashery, K. Radwan, M. Gar Alalm (2010) The effect of pH control on turbidity and NOM removal in conventional water treatment. Int Water Technol J 1(2): 1-16.

[44]. M. Gar Alalm, M. Nasr, S. Ookawara, (2016) Assessment of a novel spiral hydraulic flocculation/sedimentation system by CFD simulation, fuzzy inference system, and response surface methodology. Sep Purif Technol 169: 137-150.

[45]. H. Lotfy, I. Rashed (2002) A method for treating wastewater containing form aldehyde. Water Res 36(3): 633-637.

[46]. M. Gar Alalm, M. Nasr (2018) Artificial intelligence, regression model, and cost estimation for removal of chlorothalonil pesticide by activated carbon prepared from casuarina charcoal. Sustain Environ Res.

[47]. M. Gar Alalm, A. Tawfik, S. Ookawara (2015) Combined Solar advanced oxidation and PAC adsorption for removal of pesticides from industrial wastewater. J Mater Environ Sci 6(3): 800-809.

[48]. A. Ashry, K. Radwan, M. Gar Alalm (2012) Enhanced coagulation using a spiral clari-flocculator. Int Water Technol J 2(2): 145-164. 
[49]. M. Gar Alalm, S. Ookawara, D. Fukushi, A. Sato, A. Tawfik (2016) Improved WO 3 photo catalytic efficiency using $\mathrm{ZrO} 2$ and $\mathrm{Ru}$ for the degradation of carbofuran and ampicillin. J Hazard Mater 302: 225-231.

[50]. K. Bhattacharyya, A.Sharma, (2004) Azadirachta indica leaf powder as an effective biosorbent for dyes: a case study with aqueous Congo Red solutions, Journal of Environmental Management, vol. 71, no. 3, pp. 217-229.

[51]. Y. Ho, G. McKay, (1999) Pseudo-second order model for sorption processes, Process Biochemistry, vol. 34, no. 5, pp. 451-465.

[52]. Z. Yue, S. Bender, J. Wang, J. Economy, (2009) Removal of chromium $\mathrm{Cr}$ (VI) by low cost chemically activated carbon materials from water. J Hazard Mater, 166:74-8.

[53]. I. Langmuir, (1918) The adsorption of gases on plane surfaces of glass, mica and platinum, The Journal of the American Chemical Society, vol. 40, no. 9, pp. 1361-1403.

[54]. A. Mittal, D. Kaur, A. Malviya, J. Mittal, V. Gupta, (2009) Adsorption studies on the removal of coloring agent phenol red from wastewater using waste materials as adsorbents. J Colloid Interface Sci, 337:345-54

[55]. H. Freundlich, (1906) Uber die adsorption in losungen," Zeitschrift für Physikalische Chemie, vol. 57, pp. 385-470.

[56]. B. Hameed, J. Salman, A. Ahmad, (2009) Adsorption isotherm and kinetic modeling of 2,4-D pesticide on activated carbon derived from date stones.J Hazard Mater,163:121-6.

[57]. A. Delle, (2001) Factors affecting sorption of organic compounds in natural sorbent/water systems and sorption coefficients for selected pollutants. A review, Journal of Physical and Chemical Reference Data, vol. 30 , no. 1 , pp. $187-439$.

[58]. A. Kumar, B. Prasad, I. Mishra, (2008) Adsorptive removal of acrylonitrile by commercial grade activated carbon: kinetics, equilibrium and thermodynamics. J Hazard Mater, 152:589-600.

[59]. A. El Nemr, O. Abdelwahab, A. El-Sikaily, A. Khaled, (2009) Removal of direct blue-86 from aqueous solution by new activated carbon developed from orange peel. J Hazard Mater, 161:102-10.

[60]. B. Singha, S. Das, (2012) Removal of Pb (II) ions from aqueous solution and industrial effluent using natural biosorbents, Environmental Science and Pollution Research, vol. 19, no. 6, pp. 2212-2226.

[61]. W. Ngah, S. Ghani, A. Kamari, (2005) Adsorption behaviour of Fe (II) and $\mathrm{Fe}$ (III) ions in aqueous solution on chitosan and cross-linked chitosan beads, Bioresource Technology, vol. 96, no. 4, pp. 443-450.

[62]. S. Shukla, R. Pai, A. Shendarkar, (2006) Adsorption of Ni (II), Zn (II) and Fe (II) on modified coir fibres," Separation and Purification Technology, vol. 47, no. 3, pp. 141-147.

[63]. Y. Zhang, J. Zhao, Z. Jiang, D. Shan, Y. Lu, (2014) Biosorption of Fe (II) and Mn (II) Ions from Aqueous Solution by Rice Husk Ash, Bio Med Research International Volume 2014, Article ID 973095, 10 pages.
[64]. B. Acemioğlu, (2004) Removal of Fe (II) ions from aqueous solution by Calabrian pine bark wastes, Bioresource Technology, vol. 93, no. 1, pp. 99-102.

\section{Title Arabic:}

تحسين خصائص مياه الشرب باستخدام مادة مازة حيوية مبتكرة

\section{Arabic Abstract:}

في هذه البحث كثفنا عن مادة جديدة في عالم المخثرات والمواد المادئ المازة

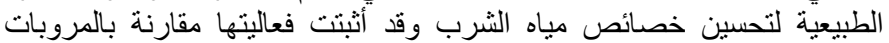

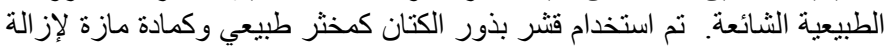

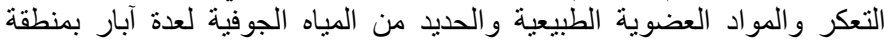

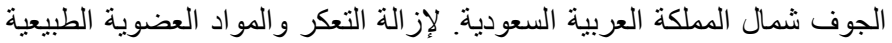

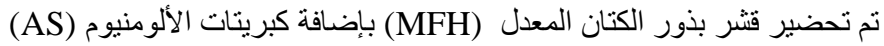

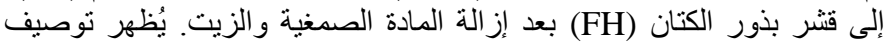

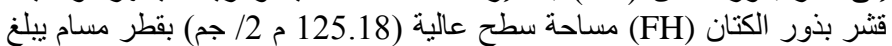

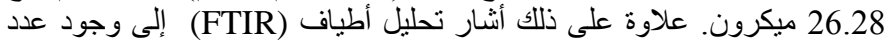

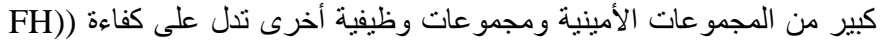

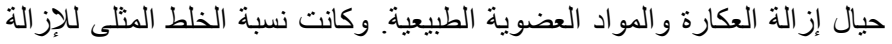

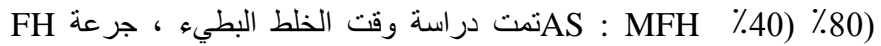

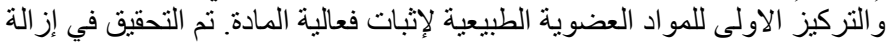

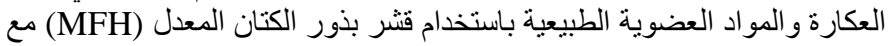

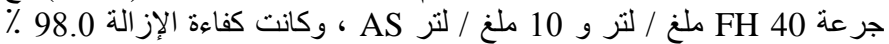

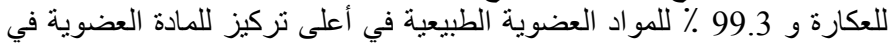

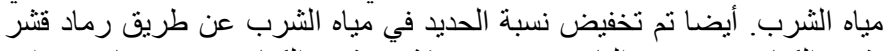

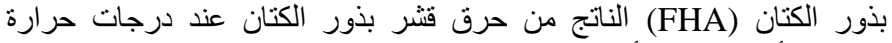

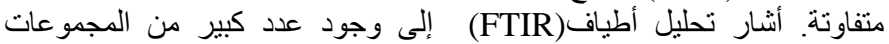

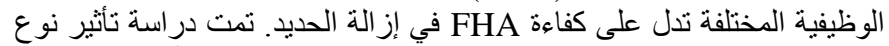

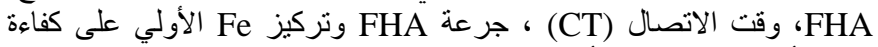

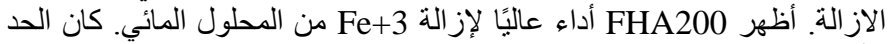
الأقصى للإزالة 90\% باستخدام جرعة 0.75 جرام / لتر من الإل

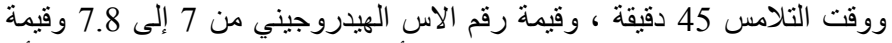

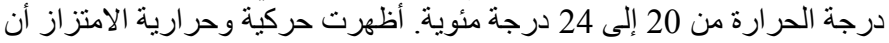
كفاءة الامثزاز على سطح المادة الممتزة تنصرية الفرف بطريقة مواتية لامتصاص الحديد. 